\title{
APLIKASI WIRELESS SENSOR NETWORK UNTUK SISTEM MONITORING DAN KLASIFIKASI KUALITAS UDARA
}

\author{
Tri Fidrian Arya, Mahar Faiqurahman, dan Yufis Azhar \\ Teknik Informatika, Fakultas Teknik, Universitas Muhammadiyah Malang (UMM) \\ Jln. Raya Tlogomas No. 246, Malang, 65144, Indonesia \\ E-mail: trifidrianarya@gmail.com,mahar@umm.ac.id,yufis@umm.ac.id
}

\begin{abstract}
Indonesia is one of the countries investing in the industrial sector. Industries affect the environment, notably air quality. If the air pollution expelled by industrial chimneys could not be processed properly, it would adversely affect human health. Currently, monitoring the air quality in some areas only uses one tool. This is deemed inadequate to describe the condition of air quality in a given area. On the other hand, installing more than one tool would be very expensive. This research applied the concept of wireless sensor network (WSN) for air quality monitoring by installing more than one sensor nodes in a particular location and one sink that acts to collect data from the sensor nodes then sends them to the server. Air quality data obtained by the sensor nodes were then classified using the classification method in data mining that is k-nearest neighbor (K-NN). Prior to classification using K-NN, data normalization was performed, which generates a decimal scaling with good performance for air quality data. The $\mathrm{k}$ values used for the K-NN classification are 5. The accuracy of the system is $94.28 \%$, the precision is $85.16 \%$ and the recall is $93.35 \%$.
\end{abstract}

Keywords: Wireless Sensor Network, Data Mining, Classification, K-NN, Air Quality.

\begin{abstract}
Abstrak
Indonesia merupakan salah satu negara yang bergerak di sektor industri. Perindustrian memberikan dampak pada lingkungan hidup, termasuk kualitas udara. Jika polusi udara yang dikeluarkan dari cerobong asap kawasan industri tidak diproses dengan baik, polusi tersebut akan berdampak buruk pada kesehatan manusia. Saat ini, pemantauan kualitas udara terhadap suatu cakupan lokasi tertentu hanya menggunakan satu alat saja. Hal ini dirasa kurang cukup untuk menggambarkan kondisi kualitas udara yang ada pada suatu cakupan lokasi tersebut. Di sisi lain, instalasi lebih dari satu alat akan membutuhkan biaya yang besar. Pada penelitian ini, diaplikasikan konsep wireless sensor network (WSN) untuk pemantauan kualitas udara dengan pemasangan lebih dari satu perangkat node sensor pada lokasi tertentu dan satu sink yang bertindak untuk mengumpulkan data dari node sensor lalu mengirimkannya ke server. Data kualitas udara yang didapatkan oleh node sensor kemudian diklasifikasikan menggunakan metode klasifikasi pada data mining, yaitu k-nearest neighbor (K-NN). Sebelum dilakukan klasifikasi menggunakan K-NN, dilakukan normalisasi data yang menghasilkan decimal scaling dengan performa yang baik untuk data kualitas udara. Nilai $\mathrm{k}$ yang digunakan untuk klasifikasi K-NN yaitu 5. Didapatkan tingkat akurasi yang dihasilkan oleh sistem sebesar 94,28\%, presisi sebesar $85,16 \%$, dan recall sebesar $93,35 \%$.
\end{abstract}

Kata Kunci: Wireless Sensor Network, Data Mining, Klasifikasi, K-NN, Kualitas Udara.

\section{Pendahuluan}

Indonesia merupakan salah satu negara yang memiliki perkembangan yang pesat pada sektor industri, hal tersebut tentunya berpengaruh pada lingkungan hidup termasuk kualitas udara [1]. Menurut Supraptini [2], polusi udara yang dikeluarkan dari cerobong asap kawasan industri apabila tidak dikelola dengan baik akan berdampak buruk pada kesehatan manusia, di antaranya dapat berpengaruh terhadap status faal paru-paru, perubahan respon kekebalan tubuh, bahkan menyebabkan kematian pada makhluk hidup. Telah dijelaskan dalam peraturan pemerintah pentingnya udara bagi kehidupan, sehingga perlu dilestarikan serta dijaga fungsinya melalui pengendalian pencemaran udara [3].

Oleh karena itu, monitoring tingkat polusi udara menjadi suatu hal yang urgent dilakukan. Di Indonesia, monitoring kualitas udara saat ini hanya menggunakan satu alat saja dan dalam cakupan lokasi tertentu, sehingga kurang dapat menggambarkan kondisi kualitas udara yang ada. Diperlukan lebih sari satu alat untuk secara efektif 
melakukan pemantauan dalam cakupan lokasi tersebut. Untuk menanggulangi hal ini, dapat mengaplikasikan Wireless Sensor Network (WSN). WSN adalah teknologi yang melakukan proses sensing, kontrol, dan komunikasi untuk monitoring lingkungan secara pengukuran fisik [4]. WSN terdiri dari beberapa node sensor, serta base station yang diimplementasikan dan dapat saling mengirimkan data menggunakan jaringan nirkabel. Setiap node sensor menggunakan modul jaringan nirkabel dalam komunikasinya dan mudah diterapkan pada lingkungan [5].

Terdapat beberapa penelitian yang telah mengkaji pengaplikasian Wireless Sensor Network (WSN). Pada penelitian yang telah dilakukan oleh Iwan et al [6], sistem monitoring kualitas udara dibangun menggunakan WSN, dengan parameter yang digunakan yaitu suhu, kelembaban, karbondioksida, dan karbonmonoksida. Pada penelitian ini [6], data yang didapatkan tidak dilakukan pengolahan secara lebih lanjut untuk menghasilkan informasi klasifikasi kualitas udara. Penelitian yang dilakukan oleh Xu dan Liu [7], yaitu melakukan monitoring kualitas air dengan menggunakan parameter kelarutan oksigen, tekanan air, PH, dan temperatur dengan mengaplikasikan WSN. Penelitian aplikasi WSN dengan judul "Wireless Sensor Network System Design using Raspberry Pi and Arduino for Environmental Monitoring Applications" [8] mengaplikasikan modul arduino dan Xbee untuk komunikasi nirkabel, hanya saja modul Xbee tersebut memiliki biaya yang cukup tinggi dalam pengadaannya.

Penelitian lain yang mengaplikasikan wireless sensor network dan menerapkan konsep klasifikasi data minig di antaranya, Laksono et al [9] mengaplikasikan wireless sensor network untuk membuat prediksi cuaca dengan menggunakan paramter sensor angin, suhu, dan kelembaban, dengan menggunakan metode C4.5. Pada penelitian Sugiarto dan Sustika [10], dilakukan pengklasifikasian data kualitas udara dengan fitur yang digunakan yaitu suhu, kelembaban, karbondioksida, dan karbon monoksida, kemudian pengklasifikasian dilakukan menggunakan metode decision tree. Saoudi et al [11], melakukan penelitian mengaplikasikan WSN untuk mendeteksi kebakaran hutan. Node sensor pada penelitian ini [11] melakukan pemantauan suhu, kelembaban, intensitas cahaya, dan intensitas asap, kemudian dilakukan pengklasifikasian data pada server untuk mengetahui apakah terjadi kebakaran hutan atau tidak dengan menggunakan Artificial Neural Network pada data mining.

Pada penelitian ini dibuat aplikasi berbasis Wireless Sensor Network (WSN) untuk monitoring dan klasifikasi kualitas udara secara online, dengan menggunakan modul LoRa untuk komunikasi antara node sensor dan base station yang biayanya cukup terjangkau dan jarak komunikasi yang relatif besar pula dibandingkan beberapa modul komunikasi wireless yang lain seperti Xbee. Penyebaran node sensor dilakukan pada titik-titik lokasi tertentu, misalnya di dekat jalan raya, perumahan, kawasan industri, dan sebagainya dengan parameter yang digunakan di antaranya karbonmonoksida, ozon, dan kadar partikulat di udara. Nilai dari parameter tersebut didapatkan dari proses sensing oleh sensor secara berkala.

\section{Metode}

Dalam penelitian ini akan diaplikasikan konsep wireless sensor network untuk sistem monitoring dan klasifikasi kualitas udara, di mana perangkat yang dibangun dan digunakan untuk pemantauan tingkat kadar karbonmonoksida $(\mathrm{CO})$, ozon $\left(\mathrm{O}_{3}\right)$, dan partikulat (PM10) di udara. Kemudian dari hasil pemantauan (sensing) tersebut akan dilakukan klasifikasi kualitas udara lingkungan, apakah baik, sedang, atau tidak sehat. Untuk proses klasifikasi digunakan salah satu teknik yang ada di data mining yaitu metode K-Nearest Neighbor.

\section{Analisis Data}

Data yang digunakan dalam penelitian ini merupakan data nilai dari parameter karbon monoksida $(\mathrm{CO})$, ozon $\left(\mathrm{O}_{3}\right)$, dan partikulat udara (PM10). Data tersebut digunakan menjadi data latih untuk proses klasifikasi nantinya. Tiga parameter tersebut sesuai dengan keputusan kepala bapedal indek standar pencemaran udara (ISPU) [12]. Data pada penelitian ini didapatkan dari website dinas lingkungan hidup dari beberapa daerah di Indonesia. Pendekatan yang dapat digunakan untuk proses klasifikasi digunakan algoritma K-Nearest Neighbor (K-NN). Algoritma $\mathrm{K}-\mathrm{NN}$ dipilih karena data tingkat kadar $\mathrm{CO}, \mathrm{O} 3$, dan PM10 yang dipantau berupa angka, dan metode K-NN dalam proses klasifikasi data menggunakan kedekatan jarak antara data uji dengan setiap data yang terdapat pada data latih. Berikut beberapa contoh format data kualitas udara pada Tabel 1.

TABEL 1

DATA KUALITAS UDARA

\begin{tabular}{ccccc}
\multicolumn{6}{c}{ DATA KUALITAS UDARA } \\
\hline $\begin{array}{c}\text { Data } \\
\text { ke }\end{array}$ & $\begin{array}{c}\text { CO } \\
\text { (PPM) }\end{array}$ & $\begin{array}{c}\text { O3 } \\
\text { (PPM) }\end{array}$ & $\begin{array}{c}\text { PM10 } \\
\text { (PPM) }\end{array}$ & Label \\
\hline 1 & 0,692692 & 8,175989 & 45,05 & $\begin{array}{c}\text { tidak } \\
\text { sehat } \\
\text { tidak } \\
\text { sehat }\end{array}$ \\
2 & 0,83508 & 8,175989 & 67,78 & $\begin{array}{c}\text { tidak } \\
\text { tidat }\end{array}$ \\
3 & 0,499352 & 8,138137 & 48,36 & $\begin{array}{l}\text { sehat } \\
\text { tidak }\end{array}$
\end{tabular}




\begin{tabular}{|c|c|c|c|c|}
\hline 5 & 0,703906 & 12,08419 & 43,7 & $\begin{array}{l}\text { sehat } \\
\text { tidak } \\
\text { sehat }\end{array}$ \\
\hline 6 & 0,591964 & 9,898246 & 51,01 & sedang \\
\hline 7 & 0,88617 & 9,794153 & 55,21 & sedang \\
\hline 8 & 0,40288 & 8,086091 & 89,22 & sedang \\
\hline 9 & 0,680368 & 13,57933 & 32,25 & sedang \\
\hline 10 & 0,520717 & 3,345153 & 33,3 & sedang \\
\hline 11 & 1,121146 & 4,807179 & 65,4 & baik \\
\hline 12 & 0,373837 & 4,168429 & 10,29 & baik \\
\hline 13 & 0,800799 & 1,47622 & 17,21 & baik \\
\hline 14 & 0,780917 & 2,408321 & 15,86 & baik \\
\hline 15 & 6,600995 & 99,42201 & 192,516 & baik \\
\hline
\end{tabular}

\section{Desain Arsitektur Sistem}

Pada penelitian ini arsitektur wireless sensor network (WSN) yang digunakan terdiri dari sink node, node sensor, dan komputer server. Topologi yang digunakan pada sistem WSN penelitian ini yaitu topologi star yang mana setiap node sensor langsung terhubung dengan sink. Pada Gambar 1 merupakan arsitektur WSN yg diimplementasikan.

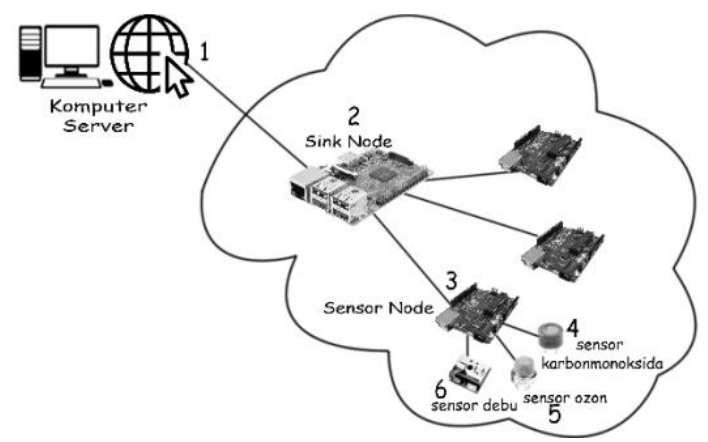

Gambar 1. Arsitektur sistem WSN yang diaplikasikan

Keterangan :

1. Komputer server yang berfungsi untuk monitoring dan klasifikasi kualitas udara

2. Sink merupakan mini komputer menggunakan perangkat Raspberry Pi 3 Model B dan ditambah Arduino.

3. Node sensor merupakan perangkat mikrokontroler menggunakan Arduino Uno.

4. Sensor MQ-7 yang digunakan untuk mengukur tingkat gas karbonmonoksida.

5. Sensor MQ-131 yang digunakan untuk mengukur tingkat gas ozon $\left(\mathrm{O}_{3}\right)$.

6. Sensor GP2Y1010AU0F yang digunakan untuk mengukur tingkat partikulat debu diudara.

Error! Reference source not found.Gambar 1 merupakan arsitektur WSN yang diimplementasikan terdiri dari komponen node sensor, sink node, dan komputer server. Node sensor yang berfungsi melakukan pengukuran lingkungan terkait kualitas udara. Hasil pengukuran node sensor dikirimkan ke sink. Sink node bertindak untuk mengumpulkan data hasil sensing oleh node sensor untuk sementara waktu. Setelah data dikumpulkan di sink, data tersebut akan dikirimkan ke komputer server untuk diolah menghasilkan klasifikasi dan menampilkan kualitas udara.

\section{Node Sensor}

Komponen yang digunakan pada node sensor yaitu papan arduino untuk menyimpan kode sumber program, sensor MQ-7 untuk melakukan sensing CO, sensor MQ-131 untuk melakukan sensing O3, sensor sharp GP2Y1010AU0F untuk melakukan sensing PM10, dan modul LoRa digunakan untuk berkomunikasi dengan sink. Gambar 2 merupakan rancangan rangkaian pada node sensor.

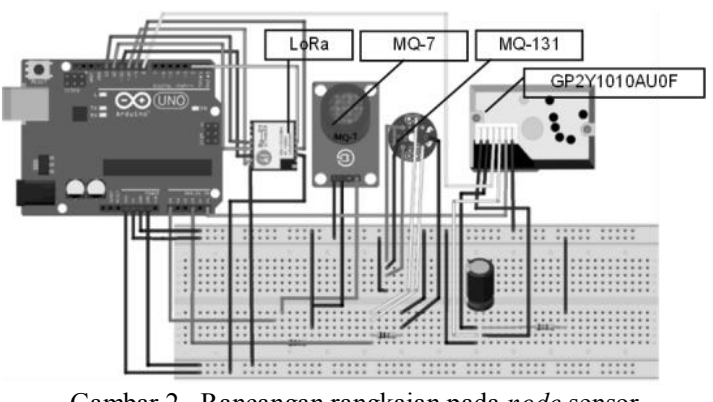

Gambar 2. Rancangan rangkaian pada node sensor

\section{Sink}

Komponen yang digunakan pada sink yaitu papan Raspberry Pi 3 model B yang telah dilengkapi modul wifi pada boardnya. Modul wifi tersebut akan digunakan untuk berkomunikasi dengan komputer server guna mengirimkan data kualitas udara. Kemudian pada sink terdapat Arduino Uno board yang dilengkapi dengan modul LoRa terhubung pada port USB Raspberry Pi yang digunakan untuk berkomunikasi guna menerima data dari node sensor.

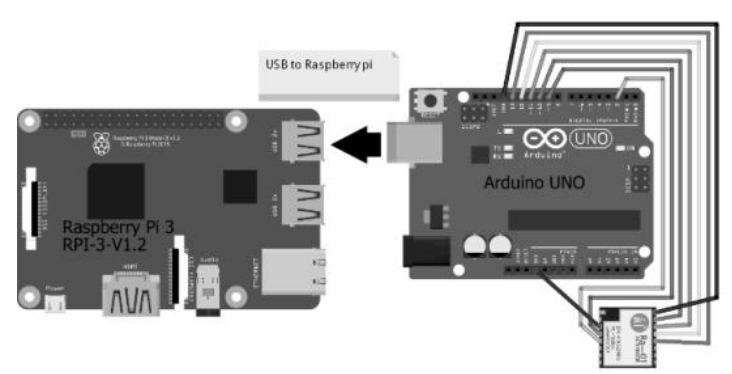

Gambar 3. Rancangan rangkaian pada sink

\section{Perancangan Proses}

Pada tahapan ini dilakukan perancangan proses untuk setiap komponen yang terdapat pada arsitektur wireless sensor network (WSN) yang diaplikasikan pada node sensor, sink, dan server sesuai fungsinya masing-masing. Gambar 4 merupakan gambaran perancangan proses.

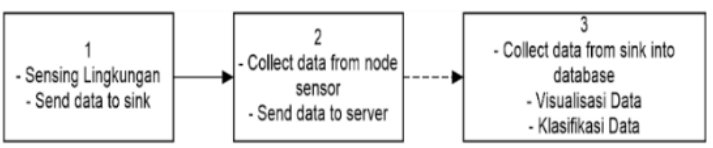

Gambar 4. Rancangan rangkaian pada sink 
Keterangan :

1. Perangkat proses pada node sensor (Mikrokontroler).

2. Perangkat proses pada sink.

3. Perangkat proses pada server.

$\rightarrow$ Jaringan Radio Frekuensi (LoRa).

$\rightarrow$ HTTP Request.

Node Sensor

Perangkat lunak pada node sensor digunakan untuk melakukan proses sensing kondisi udara dengan mengambil nilai dari parameter $\mathrm{CO}, \mathrm{O}_{3}$, dan PM10. Gambar 5 merupakan diagram alur program pada node sensor mikrokontroler.

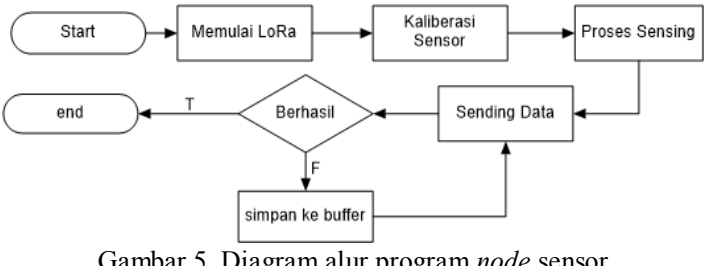

Gambar 5 di atas merupakan proses intruksi program pada node sensor yang melakukan proses pengukuran nilai $\mathrm{CO}, \mathrm{O}_{3}$, dan PM10. Proses sensing dilakukan selama 1 menit dengan data yang didapatkan \pm 40 data, kemudian dihitung nilai rata-ratanya. Nilai dari rata-rata yang didapatkan selama 1 menit tersebut kemudian dikirimkan ke sink. Apabila pengiriman yang dilakukan tidak berhasil, data yang tidak dikirimkan tersebut akan disimpan ke dalam buffer untuk sementara waktu, dan akan dikirimkan saat proses pengiriman selanjutnya.

\section{Sink}

Perangkat lunak pada sink digunakan untuk mengumpulkan data dari node sensor, kemudian dikirim ke server. Gambar 6 merupakan diagram alur perangkat lunak pada sink.

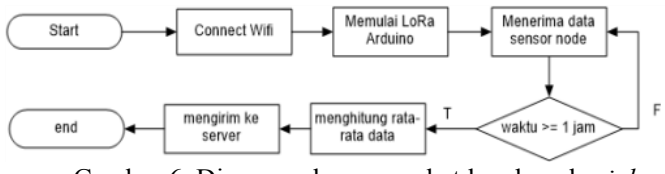

Gambar 6. Diagram alur perangkat lunak pada sink

Dari Gambar 6 di atas, sink akan menerima data yang dikirimkan oleh node sensor, kemudian akan dicatat waktu saat pertama kali menerima data dari node sensor. Proses pengiriman data ke server dilakukan setiap 1 jam dari saat menerima data pertama kali dari node sensor, ini dilakukan sesuai aturan Keputusan Kepala Bapedal No. 107 Tahun 1997. Node sensor mengirimkan data ke sink setiap 1 menit, maka pada sink akan terdapat 60 data tingkat kadar $\mathrm{CO}, \mathrm{O}_{3}$, dan PM10 sebelum data dikirimkan ke server. Dari 60 data tersebut dihitung nilai rata-ratanya, kemudian dikirimkan ke server. Pengiriman data ke server menggunakan protokol HTTP.

Server

Perangkat lunak pada server menerima data kualitas udara dari sink. Setelah menerima data dari sink, server akan melakukan klasifikasi data yang diterima, lalu memasukan data dan hasil klasifikasinya ke dalam basis data yang tersedia di server. Komputer server akan menampilkan visualisasi kualitas udara. Gambar 7 adalah alur program dari penerimaan data dari sink menggunakan protokol HTTP yang akan diakses oleh server.

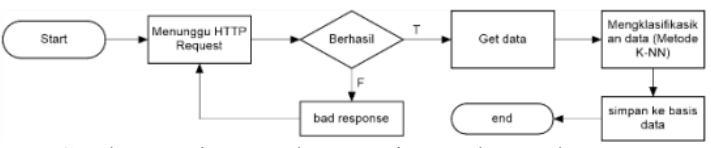

Gambar 7. Diagram alur penerimaan data pada server

Berdasarkan Gambar 7 di atas, server akan menunggu pesan HTTP yang dikirimkan oleh sink yang mengirimkan data kualitas udara yaitu tingkat kadar CO, O3, PM10. Ketika data diterima oleh server, dilakukan pengolahan klasifikasi kualitas udara dengan menggunakan metode K-NN. Setelah dihasilkan label dari data yang dikirimkan oleh sink, label disimpan ke dalam basis data yang terdapat pada server.

Pada proses pengklasifikasian data di server menggunakan konsep data mining, yaitu menggunakan metode K-Nearest Neighbor (K$\mathrm{NN}$ ). Tahapan normalisasi data dilakukan berupa penyamaan skala atau jarak pada setiap fitur yang ada pada data latih dan data yang akan diklasifikasikan, dikarenakan data yang diterima oleh server memiliki skala dari setiap fitur beragam.

Standar jarak (normalisasi) yang digunakan yaitu z-score, min-max, dan decimal scaling. Dari 3 normalisasi tersebut akan dicari manakah yang memiliki tingkat performa untuk klasifikasi data yang baik. Error! Reference source not found. merupakan alur pengklasifikasian menggunakan data mining.

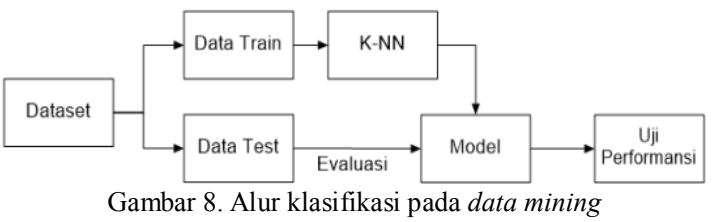

Algoritma dalam K-NN seperti di bawah ini.

a. Memasukkan nilai $\mathrm{k}$ (jumlah data latih yang terdekat).

b. Melakukan normalisasi data untuk penyamaan skala dari setiap parameter data. 
Penelitian ini menggunakan 3 variasi normalisasi, yaitu:

-Z-score, formula yang digunakan :

$$
\mathrm{v}^{\prime}=\frac{\mathrm{v}-\mu}{\sigma}
$$

Di mana, $v^{\prime}=$ nilai standarisasi; $v=$ nilai dari atribut; $\mu=$ rata-rata; $\sigma=$ standar deviasi.

-Min-Max, formula dari normalisasi min-max:

$$
\mathrm{v}^{\prime}=\frac{\mathrm{v}-\mathrm{v}_{\min }}{\mathrm{v}_{\max }-\mathrm{v}_{\min }}
$$

-Decimal Scaling, formula decimal scaling:

$$
\mathrm{v}^{\prime}=\frac{\mathrm{v}}{10^{\mathrm{j}}}
$$

Di mana $\mathrm{j}=$ nilai scaling yang diinginkan

c. Menghitung jarak terdekat antara data yang akan diklasifikasikan dengan setiap data yang ada pada data latih dengan menggunakan pengukuran euclidean distance.

Persamaan euclidean distance :

$$
D(x, y)=\sqrt{\sum_{i=1}^{n}\left(x_{i}-y_{i}\right)^{2}}
$$

d. Melakukan pengurutan data yang terdekat dari nilai hasil perhitungan jarak terkecil.

e. Memilih label dengan frekuensi terbanyak.

\section{Hasil dan Analisis}

\section{Implementasi Node Sensor}

Gambar 9 merupakan print screen perangkat lunak pada node sensor saat melakukan proses sensing dan pengiriman data ke sink. Dari gambar di bawah ini dapat dilihat apabila node sensor dapat mengirimkan data ke sink maka status pengirimannya 1 dan jika tidak maka 0 . Selain status pengiriman, node sensor akan menampilkan data yang dikirimkan oleh node sensor ke sink.

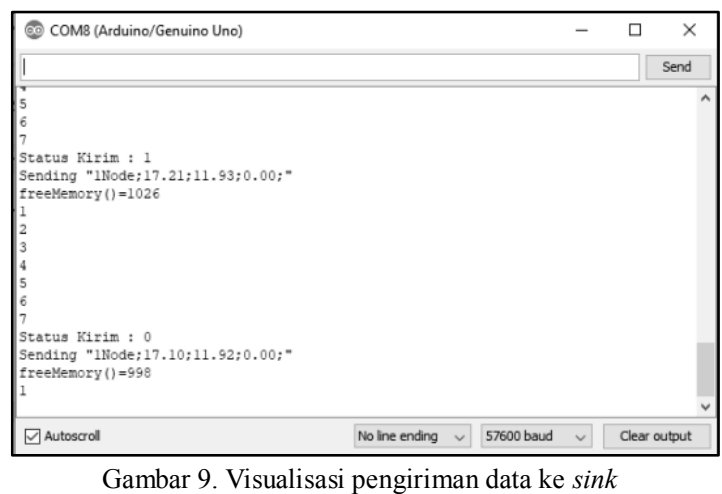

\section{Implementasi Sink}

Di bawah ini Gambar 10 merupakan print screen perangkat lunak yang terdapat pada sink. Sink akan menampilkan data yang diterima dari node sensor.
Gambar 11 merupakan visualisasi program saat sink melakukan pengiriman data ke server. Data yang dikirimkan yaitu ID sensor, waktu sensing, dan nilai dari paramter kualitas udara. Setelah data berhasil dikirimkan ke server, server akan memberikan respon JSON data dari sink.

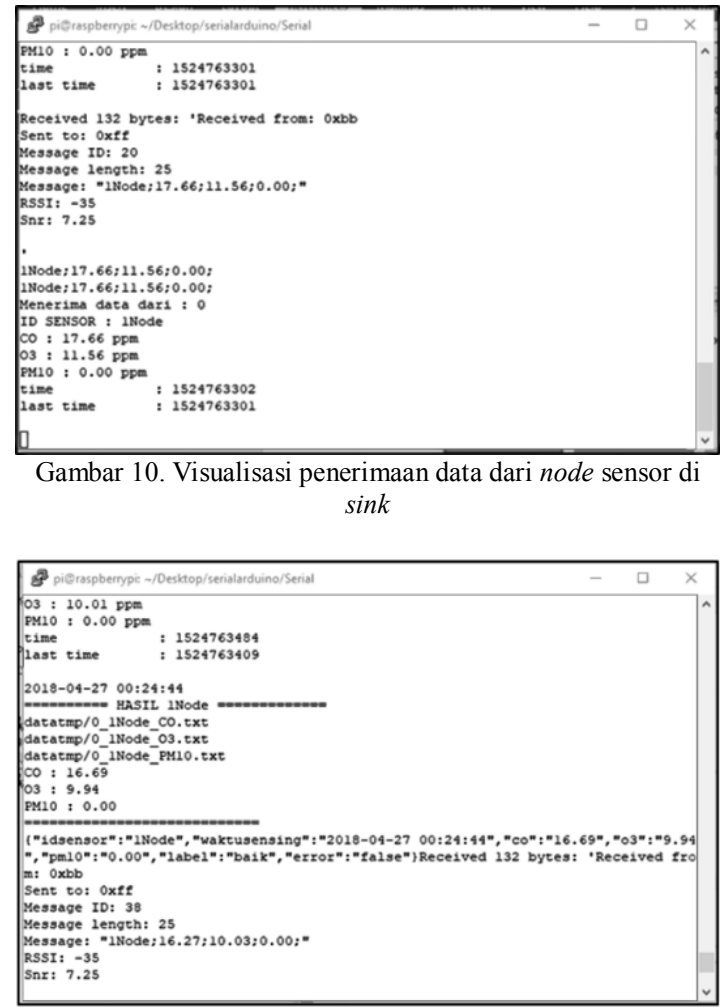

Gambar 11. Visualisasi pengiriman data dari sink ke server

\section{Implementasi Server}

Gambar 12 merupakan visualiasi data pemantauan kualitas udara dengan parameter nilai karbonmonoksida $(\mathrm{CO})$, ozon $\left(\mathrm{O}_{3}\right)$, partikulat debu (PM10), dan hasil klasifikasi kualitas udaranya yang merupakan hasil pemantauan yang didapatkan oleh node sensor.

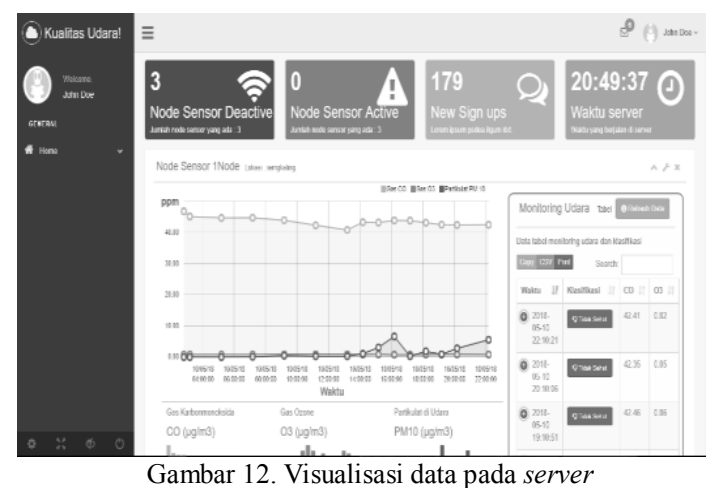

Pengujian Penggunaan SRAM dan Flash Memory Sensor Node 
Pengujian ini dilakukan dengan skenario, untuk mengetahui sisa penggunaan SRAM dan flash memory pada arduino (node sensor) terhadap variasi jumlah array buffer yang digunakan untuk menyimpan data ketika node sensor tidak dapat menjangkau atau mengirimkan data ke sink. Pengujian ini dilakukan untuk memaksimalkan penggunaan resource pada arduino. SRAM pada arduino UNO sebesar $2 \mathrm{~K}$ byte dan flash memory sebesar $32 \mathrm{~K}$ byte.

TABEL II

PENGGUNAAN SRAM DAN FLASH MEMORY

\begin{tabular}{|c|c|c|c|c|c|}
\hline $\begin{array}{c}\text { Jumlah } \\
\text { inisialisa } \\
\text { si } \text { buffer } \\
\text { awal }\end{array}$ & $\begin{array}{c}\text { sisa } \\
\text { SRA } \\
\text { M } \\
\text { awal } \\
\text { (byte) }\end{array}$ & $\begin{array}{c}\text { sisa } \\
\text { flash } \\
\text { memo } \\
r y \\
\text { (byte) }\end{array}$ & $\begin{array}{c}\text { jumla } \\
\text { h } \\
\text { buffer } \\
\text { yang } \\
\text { dapat } \\
\text { terisi } \\
\text { dan } \\
\text { tidak } \\
\text { error } \\
\end{array}$ & $\begin{array}{c}\text { sisa } \\
\text { SRA } \\
\text { M } \\
\text { akhir } \\
\text { (byte) }\end{array}$ & keterangan \\
\hline 100 & 864 & $\begin{array}{c}1975 \\
6 \\
\end{array}$ & 6 & 172 & tidak sesuai \\
\hline 80 & 992 & $\begin{array}{c}2010 \\
2 \\
\end{array}$ & 13 & 192 & tidak sesuai \\
\hline 60 & 1112 & $\begin{array}{c}2010 \\
2 \\
\end{array}$ & 23 & 181 & tidak sesuai \\
\hline 40 & 1232 & $\begin{array}{c}2010 \\
2 \\
\end{array}$ & 31 & 192 & tidak sesuai \\
\hline 33 & 1274 & $\begin{array}{c}2010 \\
2\end{array}$ & 33 & 208 & sesuai \\
\hline 32 & 1280 & $\begin{array}{c}2010 \\
2 \\
\end{array}$ & 32 & 272 & sesuai \\
\hline 30 & 1292 & $\begin{array}{c}2010 \\
2\end{array}$ & 30 & 346 & $\begin{array}{c}\text { kurang } \\
\text { memaksimalk } \\
\text { an resource }\end{array}$ \\
\hline 25 & 1322 & $\begin{array}{c}2010 \\
2\end{array}$ & 25 & 504 & $\begin{array}{c}\text { kurang } \\
\text { memaksimalk } \\
\text { an resources }\end{array}$ \\
\hline
\end{tabular}

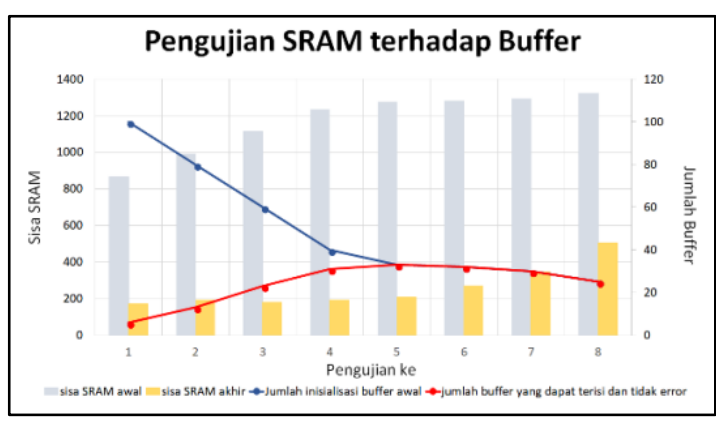

(a)

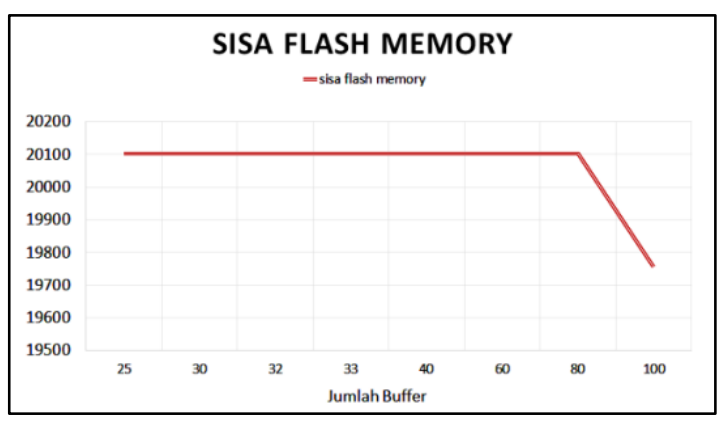

(b)
Gambar 13. Penggunaan SRAM dan flash memory

(a) Grafik sisa SRAM pada arduino berbanding dengan variasi jumlah buffer;

(b) Grafik sisa flash memory pada arduino berbanding dengan variasi jumlah array buffer

Dari Tabel II dan Gambar 13 di atas dapat dilihat penggunaan variasi jumlah buffer berpengaruh pada sisa SRAM dan flash memory pada arduino. Apabila sisa dari SRAM arduino kurang dari 200 byte, arduino akan mengalami kegagalan sistem (system error). Jumlah buffer yang sesuai untuk memaksimalkan sumber daya SRAM pada arduino yaitu sekitar 33 dan 32 jumlah buffer.

\section{Pengujian Jarak Komunikasi LoRa (SX1278)}

Pengujian ini dilakukan untuk mengetahui jangkauan modul LoRa untuk melakukan pengiriman data dari node sensor ke sink. Pengujian ini dilakukan dengan skenario dengan variasi jarak antara node sensor dan sink, dan buffer array yang terisi, jumlah buffer array yang diinisialisasi berjumlah 33 (disesuaikan dengan pengujian sebelumnya pada Tabel II Penggunaan SRAM dan flash memory).

TABEL III

PENGUKURAN JARAK LORA (SX1278)

\begin{tabular}{cccc}
\multicolumn{4}{c}{ PENGUKURAN JARAK LORA (SX1278) } \\
\hline Pengujian & $\begin{array}{c}\text { Jarak } \\
(\mathbf{m})\end{array}$ & $\begin{array}{c}\text { Maksimal } \\
\text { Buffer } \\
\text { Terisi }\end{array}$ & keterangan \\
\hline $\mathbf{1}$ & 30 & 0 & stabil \\
\hline $\mathbf{2}$ & 60 & 0 & stabil \\
\hline $\mathbf{3}$ & 90 & 0 & stabil \\
\hline $\mathbf{4}$ & 150 & 0 & stabil \\
\hline $\mathbf{5}$ & 200 & 0 & stabil \\
\hline $\mathbf{6}$ & 220 & 10 & tidak stabil \\
\hline $\mathbf{7}$ & 240 & 33 & $\begin{array}{c}\text { gagal } \\
\text { terkirim }\end{array}$ \\
\hline
\end{tabular}

Pada Tabel III di atas dapat dilihat pada jarak kurang dari 200 meter, pengiriman data dari node sensor ke sink stabil. Kemudian pengujian dari jarak 200 sampai kurang dari 220 meter pengiriman data tidak stabil. Kemudian pada saat jarak lebih dari atau sama dengan 240 meter, pengiriman data tidak dapat dilakukan.

\section{Pengujian Kehilangan Data (Missing Data Handling)}

Pengujian ini dilakukan untuk menangani data saat sink tidak dapat dijangkau atau diakses oleh node sensor, yang dapat diakibatkan karena ketidakstabilan jaringan antara node sensor dan sink menggunakan modul LoRa. Skenario pengujiannya, node sensor akan melakukan proses sensing sampai 1 menit (dalam penelitian ini waktu sensing 1 menit). Kemudian jumlah data yang 
didapatkan selama 1 menit tersebut akan dicari nilai rata-ratanya (hal ini dilakukan untuk memaksimalkan pengolahan intruksi pada arduino), kemudian dikirimkan ke sink. Apabila sink tidak dapat diakses oleh node sensor, data tersebut akan disimpan ke dalam buffer. Hal tersebut dimaksudkan agar data tidak hilang saat sink tidak dapat diakses oleh node sensor. Jumlah array yang digunakan sejumlah 33 buffer (disesuaikan dengan pengujian sebelumnya Tabel II Penggunaan SRAM dan flash memory). Apabila data yang terdapat pada buffer array telah mencapai 33 data dan data sensing oleh node sensor selanjutnya dihasilkan saat sink masih tidak dapat diakses, data pada array buffer yang lama akan diganti dengan data sensing yang baru. Saat node sensor dapat mengakses sink, maka semua array pada buffer akan langsung dikirimkan oleh node sensor ke sink secara satu persatu. Pengujian fungsi dari buffer dapat dilihat pada Tabel III Pengukuran jarak LoRa (SX1278).

\section{Pengujian nilai k untuk klasifikasi K-NN}

Pengujian nilai $\mathrm{k}$ pada $\mathrm{K}-\mathrm{NN}$ ini dilakukan untuk mengetahui nilai $\mathrm{k}$ yang sesuai dengan tingkat akurasi yang tinggi. Pengujian nilai $\mathrm{k}$ dilakukan dengan skenario dengan variasi nilai $\mathrm{k}$ pada metode K-NN dengan 3 jenis normalisasi. Tabel IV merupakan pengujian nilai $\mathrm{k}$ klasifikasi K-NN pada sistem.

Dari Tabel IV Nilai k untuk K-NN dengan variasi normalisasi dan Gambar 14 Akurasi klasifikasi sistem, didapatkan beberapa nilai $\mathrm{k}$ untuk normalisasi $z$-score memiliki tingkat akurasi yang tinggi yaitu 3, 9, 11, 13 sebesar 97,01\%. Normalisasi min-max didapatkan nilai $\mathrm{k}$ yang memiliki akurasi paling tinggi, yaitu 3 sebesar 97,01\%. Normalisasi decimal scaling didapatkan beberapa nilai $\mathrm{k}$ dengan tingkat akurasi yang tinggi yaitu 3, 5, dan 12 sebesar $98,51 \%$.

TABEL IV
NILAI K UNTUK K-NN DENGAN VARIASI NORMALISASI

\begin{tabular}{|c|c|c|c|}
\hline \multirow[b]{2}{*}{$\begin{array}{c}\text { Nilai } \\
\mathbf{k}\end{array}$} & \multicolumn{3}{|l|}{ Normalisasi } \\
\hline & $\begin{array}{l}\text { Akurasi } \\
\text { Z-Score }\end{array}$ & $\begin{array}{c}\text { Akurasi } \\
\text { Min- } \\
\text { max }\end{array}$ & $\begin{array}{l}\text { Akurasi } \\
\text { Decimal } \\
\text { Scaling }\end{array}$ \\
\hline 3 & $97,01 \%$ & $97,01 \%$ & $98,51 \%$ \\
\hline 4 & $95,52 \%$ & $95,52 \%$ & $97,01 \%$ \\
\hline 5 & $95,52 \%$ & $95,52 \%$ & $98,51 \%$ \\
\hline 6 & $95,52 \%$ & $95,52 \%$ & $94,03 \%$ \\
\hline 7 & $95,52 \%$ & $95,52 \%$ & $95,52 \%$ \\
\hline 8 & $94,03 \%$ & $94,03 \%$ & $94,03 \%$ \\
\hline 9 & $97,01 \%$ & $95,52 \%$ & $95,52 \%$ \\
\hline 10 & $95,52 \%$ & $92,54 \%$ & $95,52 \%$ \\
\hline 11 & $97,01 \%$ & $95,52 \%$ & $95,52 \%$ \\
\hline 12 & $95,52 \%$ & $92,54 \%$ & $98,51 \%$ \\
\hline 13 & $97,01 \%$ & $94,03 \%$ & $95,52 \%$ \\
\hline 14 & $95,52 \%$ & $94,03 \%$ & $94,03 \%$ \\
\hline 15 & $95,52 \%$ & $95,52 \%$ & $95,52 \%$ \\
\hline
\end{tabular}

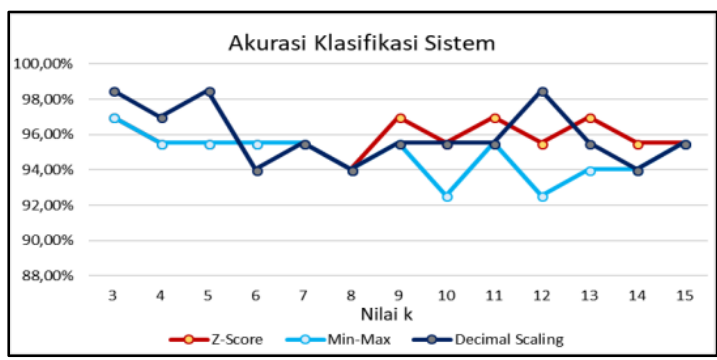

Gambar 14. Akurasi klasifikasi sistem

\section{Pengujian Akurasi Klasifikasi dengan K-Fold Cross Validation}

Pengujian ini dilakukan untuk mengetahui tingkat stabilitas hasil akurasi, presisi, dan recall terhadap hasil klasifikasi yang dihasilkan sistem jika diuji dengan data train (latih) dan data test (uji) yang bervariasi.

Dari Tabel IV pengujian nilai k pada K-NN sebelumnya untuk normalisasi $z$-score akurasi paling tinggi didapatkan dengan menggunakan nilai $\mathrm{k}$ untuk klasifikasi $\mathrm{K}-\mathrm{NN}$ yaitu 11 , nilai $\mathrm{k}$ untuk normalisasi min-max yaitu 3, nilai k untuk normalisasi decimal scaling yaitu 5. Tabel V merupakan evaluasi performa sistem klasifikasi dengan menggunakan pengujian 10-fold cross validation.

TABEL V

EVALUASI PERFORMA KLASIFIKASI 10-FOLD CROSS VALIDATION

\begin{tabular}{c|ccc|ccc|ccc}
\hline \multirow{2}{*}{ fold } & \multicolumn{3}{|c|}{ Z-Score } & \multicolumn{3}{c}{ Min-Max } & \multicolumn{3}{c}{ Decimal Scaling } \\
\cline { 2 - 10 } & Akurasi & Presisi & Recall & Akurasi & Presisi & Recall & Akurasi & Presisi & Recall \\
\hline $\mathbf{1}$ & $100,00 \%$ & $100,00 \%$ & $100,00 \%$ & $97,30 \%$ & $97,50 \%$ & $97,22 \%$ & $100,00 \%$ & $100,00 \%$ & $100,00 \%$ \\
$\mathbf{2}$ & $94,59 \%$ & $95,24 \%$ & $94,44 \%$ & $94,59 \%$ & $95,24 \%$ & $94,44 \%$ & $97,30 \%$ & $97,50 \%$ & $97,22 \%$ \\
$\mathbf{3}$ & $100,00 \%$ & $100,00 \%$ & $100,00 \%$ & $100,00 \%$ & $100,00 \%$ & $100,00 \%$ & $100,00 \%$ & $100,00 \%$ & $100,00 \%$ \\
$\mathbf{4}$ & $100,00 \%$ & $100,00 \%$ & $100,00 \%$ & $100,00 \%$ & $100,00 \%$ & $100,00 \%$ & $100,00 \%$ & $100,00 \%$ & $100,00 \%$ \\
$\mathbf{5}$ & $100,00 \%$ & $100,00 \%$ & $100,00 \%$ & $100,00 \%$ & $100,00 \%$ & $100,00 \%$ & $100,00 \%$ & $100,00 \%$ & $100,00 \%$ \\
$\mathbf{6}$ & $67,57 \%$ & $49,36 \%$ & $63,99 \%$ & $64,86 \%$ & $47,27 \%$ & $60,86 \%$ & $86,49 \%$ & $61,33 \%$ & $84,38 \%$ \\
$\mathbf{7}$ & $78,38 \%$ & $74,39 \%$ & $81,94 \%$ & $83,78 \%$ & $77,97 \%$ & $81,75 \%$ & $78,38 \%$ & $51,10 \%$ & $66,87 \%$
\end{tabular}


81 Jurnal Sistem Informasi (Journal of Information System), Volume 14, Issue 2, October 2018

\begin{tabular}{c|ccc|ccc|ccc}
$\mathbf{8}$ & $89,19 \%$ & $87,25 \%$ & $91,79 \%$ & $83,78 \%$ & $79,23 \%$ & $87,62 \%$ & $89,19 \%$ & $83,33 \%$ & $91,79 \%$ \\
$\mathbf{9}$ & $97,30 \%$ & $66,67 \%$ & $97,37 \%$ & $97,30 \%$ & $66,67 \%$ & $97,37 \%$ & $97,30 \%$ & $66,67 \%$ & $97,37 \%$ \\
$\mathbf{1 0}$ & $91,18 \%$ & $88,46 \%$ & $93,75 \%$ & $88,24 \%$ & $85,71 \%$ & $91,67 \%$ & $94,12 \%$ & $91,67 \%$ & $95,83 \%$ \\
\hline $\begin{array}{c}\text { Rata- } \\
\text { Rata }\end{array}$ & $\mathbf{9 1 , 8 2} \%$ & $\mathbf{8 6 , 1 4 \%}$ & $\mathbf{9 2 , 3 3 \%}$ & $\mathbf{9 0 , 9 9 \%}$ & $\mathbf{8 4 , 9 6 \%}$ & $\mathbf{9 1 , 0 9 \%}$ & $\mathbf{9 4 , 2 8 \%}$ & $\mathbf{8 5 , 1 6 \%}$ & $\mathbf{9 3 , 3 5 \%}$ \\
\hline
\end{tabular}

Dari Tabel V pengujian 10-fold cross validation yang telah dilakukan didapatkan normalisasi decimal scaling yang memiliki tingkat akurasi yang tinggi dan relatif lebih stabil dibandingkan normalisai z-score dan min-max dengan tingkat rata-rata akurasinya 94,28\%, presisinya $85,16 \%$ dan recall-nya sebesar $93,35 \%$.

\section{Kesimpulan}

Berdasarkan hasil analisis dan implementasi pada penelitian tentang aplikasi wireless sensor network untuk sistem monitoring dan klasifikasi kualitas udara ini, dapat disimpulkan beberapa pernyataan seperti di bawah ini.

Aplikasi wireless sensor network yang diterapkan sebagai sistem monitoring dan klasifikasi kualitas udara dirancang dengan menggunakan sensor MQ-7 untuk mengetahui tingkat kadar CO, sensor MQ-131 untuk mengetahui tingkat kadar $\mathrm{O}_{3}$, dan sensor GP2Y1010AU0F untuk mengetahui tingkat partikulat debu. Sementara itu, modul LoRa untuk komunikasi wireless node sensor ke sink dan protokol HTTP untuk pengiriman data dari sink ke server.

Pengujian jarak pengiriman LoRa dilakukan untuk mengetahui jarak maksimal pengiriman data. Pada penelitian ini didapatkan jarak jangkauan maksimal, yaitu 200 meter. Hasil ini berbeda dengan yang tertera dalam datasheet, yang mana jarak jangkauannya dapat sampai $10 \mathrm{~km}$. Untuk menangani missing data, digunakan buffer untuk menyimpan data sementara saat node sensor tidak dapat mengakses sink untuk mengirimkan data hasil sensing.

Untuk penanganan data saat node sensor tidak dapat mengakses sink dalam pengiriman data hasil sensing, diperlukan buffer untuk menampung data tersebut untuk sementara. Hasil pengujian terhadap jumlah buffer yang dapat ditampung pada arduino node sensor dengan memaksimalkan resources yang ada yaitu 33 jumlah buffer.

Dari hasil pengujian untuk performa klasifikasi menggunakan confusion matrix dan skenario 10-fold cross validation, hasil klasifikasi yang dihasilkan oleh sistem dengan menggunakan algoritma K-Nearest Neighbor (K-NN) adalah nilai akurasi, presisi, dan recall yang dipengaruhi oleh jenis normalisasi data yang digunakan. Normalisasi yang memiliki tingkat performa yang lebih baik pada penelitian ini, yaitu normalisasi decimal scaling dengan nilai $\mathrm{k}$ yang digunakan sebesar 5. Nilai akurasi yang didapatkan sebesar $\mathbf{9 4 , 2 8 \%}$, presisinya $\mathbf{8 5 , 1 6 \%}$, dan recall-nya sebesar $\mathbf{9 3 , 3 5 \%}$.

\section{Referensi}

[1] T. Astuti, T. Parenta, and H. Paddu, "Peranan Kegiatan Industri Pengolahan Terhadap Pencemaran Lingkungan di Sulawesi Selatan," Univ. Hasanudin, Makasar, vol. 3, no. 1, pp. 49-56, 2013.

[2] S. Supraptini, "Pengaruh Limbah Industri Terhadap Lingkungan Di Indonesia," Media Penelit. dan Pengemb. Kesehat., vol. 12, no. 2 Jun, pp. 10-19, 2002.

[3] PERATURAN PEMERINTAH REPUBLIK INDONESIA NOMOR 41 TAHUN 1999 TENTANG PENGENDALIAN PENCEMARAN UDARA. 1999.

[4] K. Sohraby, D. Minoli, and T. Znati, Wireless Sensor Networks. 2007.

[5] M. Pule, A. Yahya, and J. Chuma, "A Wireless Sensor Network Solution for Monitoring Water Quality in Botswana," 3rd Natl. Found. Sci. Technol. Dev. Conf. Inf. Comput. Sci., pp. 12-16, 2016.

[6] I. Muhammad, B. Sugiarto, and I. Sakti, "Rancang Bangun Sistem Monitoring Kualitas Udara Menggunakan Teknologi Wireless Sensor Network ( WSN )," Inkom, vol. III, no. 1, pp. 90-96, 2009.

[7] Y. Xu and F. Liu, "Application of Wireless Sensor Network in Water Quality Monitoring," 22017 IEEE Int. Conf. Comput. Sci. Eng. IEEE Int. Conf. Embed. Ubiquitous Comput., pp. 368-371, 2017.

[8] S. Ferdoush and X. Li, "Wireless sensor network system design using Raspberry Pi and Arduino for environmental monitoring applications," Procedia Comput. Sci., vol. 34, pp. 103-110, 2014.

[9] H. Budi et al., "APLIKASI WIRELESS SENSOR NETWORK ( WSN ) SEBAGAI SISTEM," vol. 1, no. 1, pp. 101-110, 2016.

[10] B. Sugiarto and R. Sustika, "Data Classification for Air Quality on Wireless Sensor Network Monitoring System Using Decision Tree Algorithm," 2016 2nd Int. Conf. Sci. Technol., pp. 172-176, 2016.

[11] M. Saoudi, R. Euler, T. Kechadi, and A. Cuzzocrea, "Energy-Efficient Data Mining 
Techniques for Emergency Detection in Wireless Sensor Networks," 2016 Intl IEEE Conf. Ubiquitous Intell. Comput. Adv. Trust. Comput. Scalable Comput. Commun. Cloud Big Data Comput. Internet People, Smart World Congr., pp. 766-771, 2016.

[12] Keputusan Kepala Bapedal No. 107 Tahun 1997 Tentang: Perhitungan Dan Pelaporan Serta Informasi Indeks Standar Pencemar Udara, no. 107. 1997.
[13] H. Electronic, "Mq-7 Gas Sensor," $M Q-7$ Datasheet. 2006.

[14] Z. W. T. C. Electronics, "Ozone Gas Sensor (Model : MQ131 High Concentration)." 2014.

[15] SHARP, "Application note of Sharp dust sensor GP2Y1010AU0F - Sheet No.: OPI3024EN," 2010. 